\title{
Submarine tectonic geomorphology of the Pliny and Hellenic Trenches reflecting the geological evolution of southern Greece
}

Rudarsko-geološko-naftni zbornik

(The Mining-Geology-Petroleum Engineering Bulletin) UDC: 550.8

DOI: $10.17794 / \operatorname{rgn} .2021 .4 \cdot 4$

Original scientific paper

\author{
Polina Lemenkova ${ }^{1}$ \\ ${ }^{1}$ Schmidt Institute of Physics of the Earth, Russian Academy of Sciences. Department of Natural Disasters, \\ Anthropogenic Hazards and Seismicity of the Earth. Laboratory of Regional Geophysics and Natural Disasters (Nr. 303). \\ Bolshaya Gruzinskaya St, 10, Bld. 1, Moscow, 123995, Russian Federation.
}

\begin{abstract}
Mapping seafloor geomorphology is a complex task requiring the integration of advanced cartographic technologies and high-resolution spatial data. This paper provides a comparative geomorphological analysis of the Hellenic Trench (HT) and the Pliny Trench (PT) located in the Eastern Mediterranean Sea, southern Greece. These trenches were formed as a result of the tectonic plate subduction in the Eastern Mediterranean Sea: the northward motion of the African and Arabian plates, complicated by the regional geological settings, such as active faults and earthquakes, which resulted in their different geomorphological forms and bathymetric shapes. Technically, this paper presents an example of the advanced scripting mapping by scripting the cartographic toolset of Generic Mapping Tools (GMT), which performs mapping through shell scripts. The maps are based on the high-quality topographic, geological and geophysical data: GEBCO, EGM96, geoid, and marine free-air gravity fields. The GMT builds upon the modules used for data processing. The region was subsetted by 'grdcut', analysed by the Geospatial Data Abstraction Library (GDAL) (gdalinfo utility), and visualized by 'grdimage'. Two segments of the trenches formed in a condition of varying geological and geophysical settings, have been modelled, visualized and compared, as representative cross-sections. As a result of the automated digitizing, spatial interpolation and sequential aggregating of GMT codes, the segments of the cross-sections were represented. The HT (Ionian segment) has an asymmetric one-sided shape; a steepness of $56.8^{\circ}$ on the NE side and $7^{\circ}$ on the SW flank. The PT has a more symmetric view; a steepness of $42.14^{\circ}$ on its NW flank and $26.66^{\circ}$ on its SE flank. The PT has a clear peak of the depths at -2600 to $-2800 \mathrm{~m}$ and the most representative data range at -5000 to $-6000 \mathrm{~m}$. The HT has a bimodal data distribution with two peaks. The most frequent data for HT is $-3200 \mathrm{~m}$ to $-3400 \mathrm{~m}$. Compared to PT, the HT is deeper. The histogram shows the peak of data for HT in the interval between -3200 to $-3400 \mathrm{~m}$ ( 135 samples) while the PT shows the peak of data in the interval at -2600 to $-2800 \mathrm{~m}$ (310 samples). Besides, 105 samples of the HT have depths exceeding $4000 \mathrm{~m}$, while only 20 samples were recorded for PT in the same interval. This paper contributes to the geomorphological studies of the general Eastern Mediterranean Sea region, particularly relating to regional seafloor mapping of the Hellenic and Pliny trenches.
\end{abstract}

\section{Keywords:}

geophysics; generic mapping tools; Hellenic Trench; cartography; geology

\section{Introduction}

The geomorphology of the seafloor, interpreted from bathymetric models, gives information about the geological processes on the Earth's surface. That is why the precise bathymetric mapping contributes to the geological studies and research. Methods of studying the seafloor and its geomorphology are diverse. These include using direct observations by specific software such as Atlas Hydrosweep DS-2, Global Positioning System (GPS) navigation and the Trimble system (Gauger et al., 2007), or indirect modelling through the magnetic and gravimetric measurements with regards to the Earth's

Corresponding author: Polina Lemenkova

pauline.lemenkova@gmail.com crust thickness and geological implications (Ramberg, 1981), geologic measurements of rock samples (Kuhn et al., 2006) or studying natural hazards such as landslides in the geological context (Krkač et al., 2021; Lemenkova et al., 2012).

Various methodological approaches are used in the GIS visualization and data analysis. These include, for example, geostatistical analysis, spatial metrics and statistical modelling in civil engineering (Klaučo et al., 2013a, 2013b; Lemenkov and Lemenkova, 2021a, 2021b; Dobrilović et al. 2021), mining and technological industrial works (Briševac et al., 2021), petrographic and geochemical analyses, studies of sedimentary rocks and seafloor characteristics (Bilić et al., 2021; Nugroho and Putra, 2020), and gravity modelling (Truffert et al., 1993). One of the largest problems for 


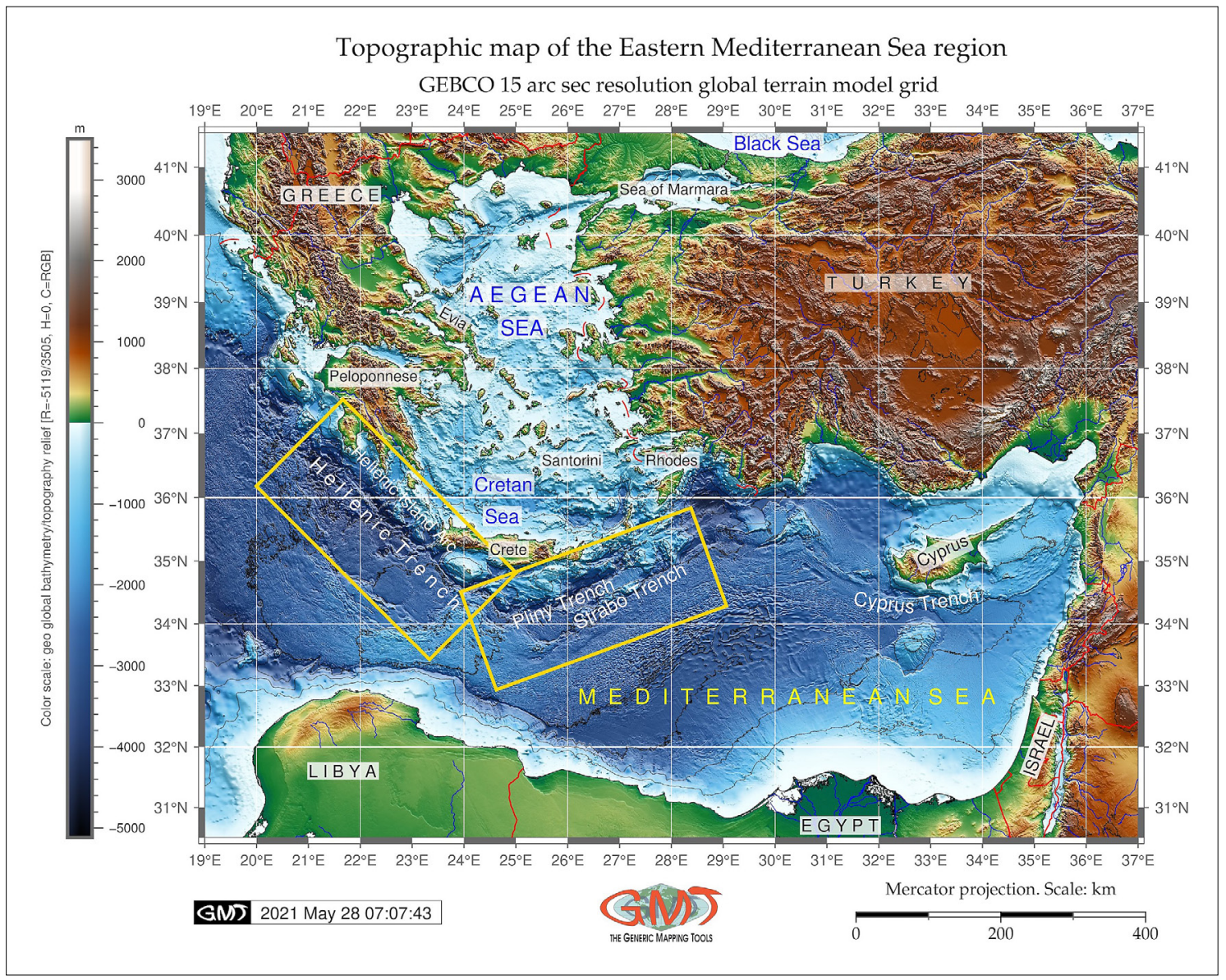

Figure 1: Topographic map of the Hellenic Trench region. Two yellow rectangles show the extent of the Hellenic and Pliny trenches.

cartographic data visualization is the processing of the multi-source data taken from various sources. This is a cartographically intensive process taking a considerable amount of workflow to process various data formats, to analyze their metadata, accuracy and suitability, often involving re-projecting and reformatting of the data. In many cases, cartographic data processing starts with generating databases that include maps of different scales, topics and statistical analysis (Suetova et al., 2005), involve advanced data analysis and planning (Klaučo et al., 2014, 2017), quantitative mapping (Rabaute and Chamot-Rooke, 2007), along with vectorizing and digitizing (Schenke and Lemenkova, 2008). Some research papers are based on the multidisciplinary analysis for studying the links between tectonic subduction and submarine geomorphology (Vassilakis et al., 2011) or using LiDAR remote sensing data applied for geology (Jagodnik et al., 2020). The advantage of the Generic Mapping Tools (GMT) as a tool for cartographic visualization and mapping is discussed previously (Lemenkova, 2020c; 2020d; 2019a).

The goal of this paper is to explore how high-resolution data can be sensibly represented as a series of the thematic maps by means of GMT, and to demonstrate the technical functionalities of GMT as useful and feasi- ble analysis and visualisation methods in geological and geomorphological studies. The paper discusses the difference in the topographic patterns of the two trenches of the Eastern Mediterranean Sea, the Hellenic Trench, and the Pliny Trench. Study of the deep-sea trenches is limited to direct observations due to their inaccessible location, and replaced by remote sensing approaches, data modelling, visualization and statistical analysis by machine learning methods (Lemenkova, 2019d, 2019a). The Hellenic Trench is placed in the eastern part of the Mediterranean Sea, the Aegean Sea (see Figure 1).

The Hellenic Trench is formed along the Mediterranean seafloor, subducted toward the northeast, below the Aegean Sea. The area surrounding the Hellenic Trench includes Southern Greece, Western Anatolia in Turkey and the basin of the Aegean Sea (McKenzie, 1970; Maravelis et al., 2016; Le Pichon and Angelier, 1979). The seafloor of the Aegean Sea has a very complex block structure. It is composed by a system of elevated blocks with steep submarine slopes. Numerous islands are located on top of these block between the depressions and elongated sub-latitudinal troughs, formed along the geologic fault system. Minor local troughs and a Hellenic Volcanic Arc are formed in the northern and southern parts of the Aegean Sea, with depths over 1200 and less than $1500 \mathrm{~m}$, respectively. 


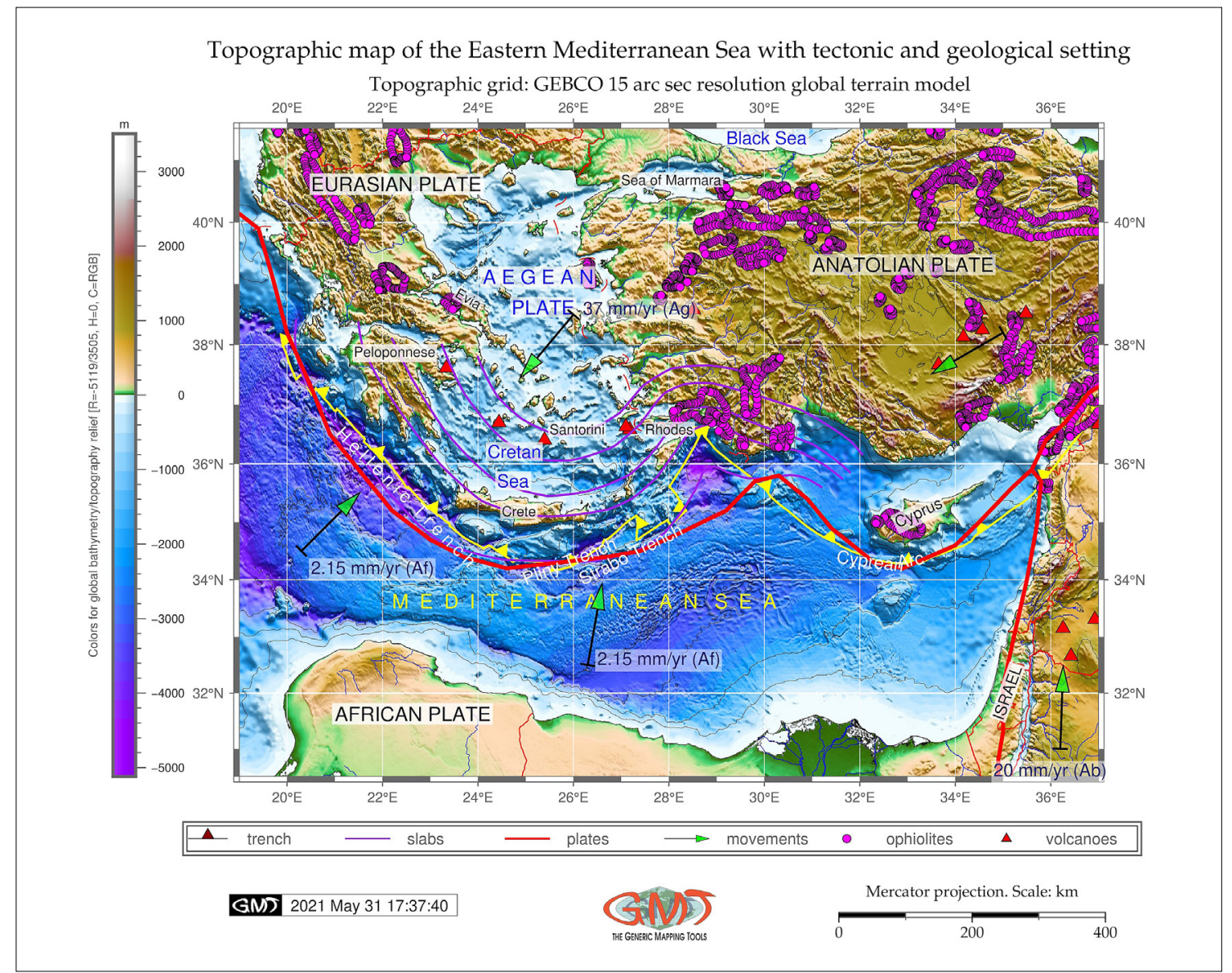

Figure 2: Topographic map of the Eastern Mediterranean Sea with tectonic and geologic setting. Illustration of the geologic setting of a study area, which contains following elements: front lines (yellow front lines),

borders of the tectonic plates (thick red lines), volcanoes (red triangles), seismic active places (focal mechanisms), ophiolites (purple small circles) showing the portions of Earth's oceanic crust uplifted and exposed above sea level and emplaced on the Anatolian and Eurasian Plates onto continental crustal rocks.

Tectonically, the Hellenic Trench is located in the zone of the lithospheric plate subduction (see Figure 2) where the African Plate is subducting under the Eurasian Plate (Angelier and Le Pichon, 1980; Le Pichon et al. 1982; Angelier et al., 1982). The Hellenic Island Arc and a trench are formed as a result of the complex interrelation of the tectonic processes and seafloor spreading (Philippon et al., 2014; McPhee and van Hinsbergen, 2019; Elsasser, 1971; Confal et al., 2016). The island arc stretches from the Ionian islands, including the Peloponnese Peninsula, the islands of Crete, Karpathos Island, Rhodes and others along the southern part of the Aegean Sea (see Figure 2). The geomorphology of the external (southern) slope of this arc is characterized by a steep slope and a complex stepwise block structure.

A system of narrow depressions is stretching along the foot of the Hellenic Island Arc forming the Hellenic Trench with dominating depths at $3500-4500 \mathrm{~m}$, and the maximum depth at $5121 \mathrm{~m}$. Le Pichon et al. (1982) reports distribution of the vertical cliffs with hard rock exposure over a depth range of 1000-1500 m of the Hellenic Trench. Following geographical specifics, the structure of the Hellenic Trench allows the differentiation into three minor trenches, sometimes referred as Ionian, Pliny and Strabo (Le Pichon et al., 1981; Peters and Huson, 1985; Özbakır et al., 2013).

The southward retreat of the Hellenic Trench resulted in the Aegean Sea extension in a two-stage period. From Middle Eocene to Middle Miocene it was accommodated by deformation leading to the exhumation of metamorphic rocks, high-temperature rocks in core complexes and the deposition of Paleogene sedimentary basins. Since Middle Miocene, the Aegean Sea extension results in a development of the Neogene sedimentary basins (see Figure 3). The process of the Aegean Sea formation is driven by slab rollback (Brun et al., 2016; Brun and Sokoutis, 2010).

The geophysical settings of the Eastern Mediterranean Sea are notable for a complex gravitational field (Tirel et al., 2004) as reflected in geoid undulations (see Figure 4). The seafloor of the Algero-Provençal Basin, the Tyrrhenian Sea and the Ionian Sea is characterized by weakly positive Faye anomalies and intense positive Bouguer anomalies (over $200 \mathrm{mGal}$ ). The values of the 


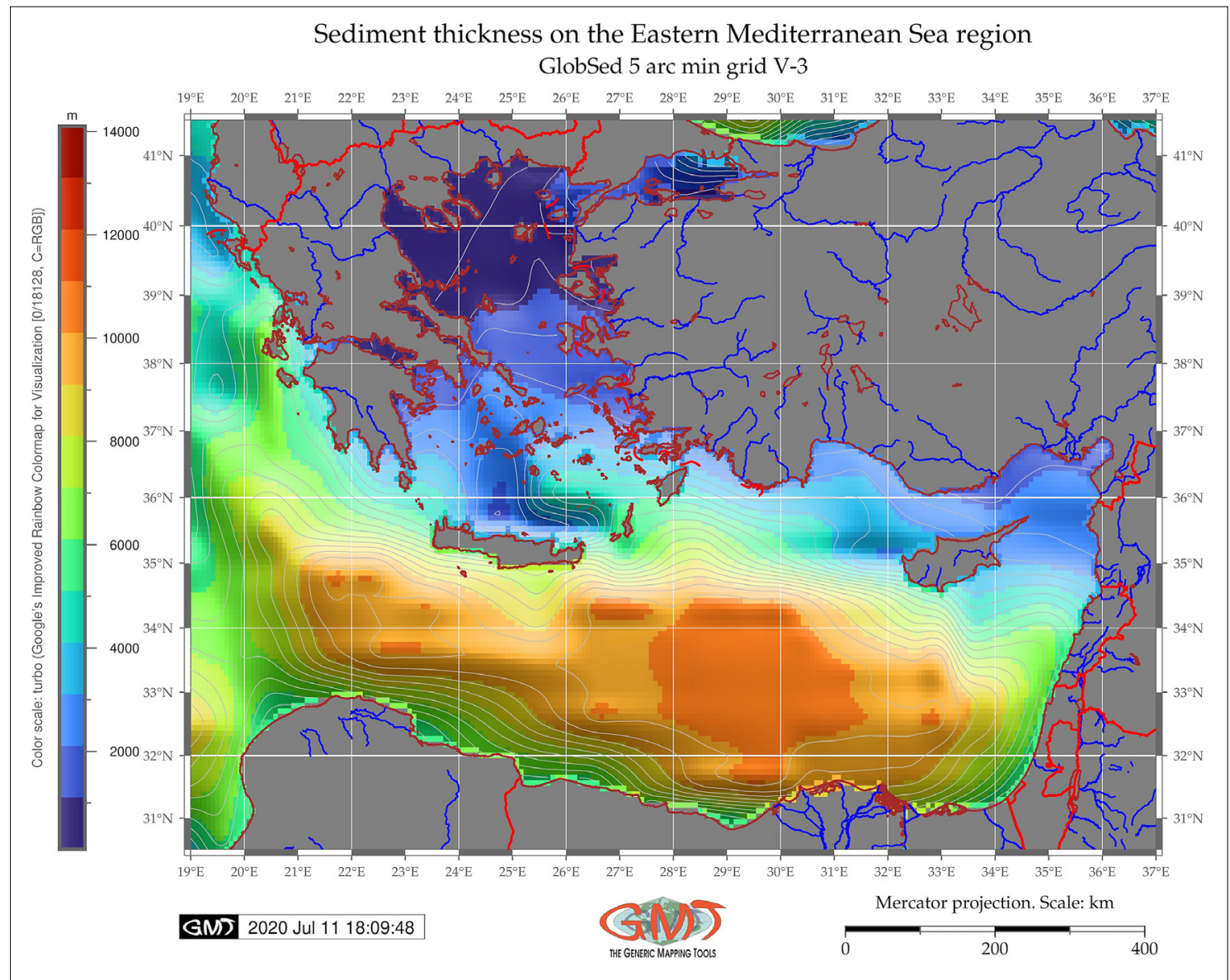

Figure 3: Sediment thickness of the Easter Mediterranean Sea basin. Sediment thickness is derived from the raster grid of Total Sediment Thickness of the World's Oceans and Marginal Seas Version 3 (GlobSed)

(Straume et al., 200o) and described by Divins (2003). The 5-arc-minute total sediment thickness grid is based on high-resolution new data and several regional observations of the oceanic sediment thickness. The isolines are placed every $500 \mathrm{~m}$ and show the increase of data (orange colours) near of the Nile River mouth.

Bouguer anomalies in the eastern part of the Mediterranean Sea are mainly from 80 to $200 \mathrm{mGal}$, decreasing to zero in some northern areas (see Figure 5). The Aegean Sea is characterized by a sharply dissected gravitational field, where Faye anomalies range from 40 to $100 \mathrm{mGal}$, and Bouguer anomalies range from 40 to $160 \mathrm{mGal}$. The negative Faye anomalies (-40 mGal to $-80 \mathrm{mGal}$ ) are observed in the eastern part of the Mediterranean Sea, except for the region of the Nile River where anomalies are positive (Malovitsky et al., 1982).

\section{Methods}

In order to examine and build a link between the tectonic and geological settings and the geomorphology of the Hellenic Trench in its western and eastern parts (the Pliny Trench) in the southern Aegean Sea, the geospatial data were visualized and a comparative analysis was divided into several phases performed by GMT (Wessel and Smith, 1991; 1995). The GMT utilizes native scripting language with its own syntax similar to the programming languages to process data. Compared to the traditional Graphical User Interface (GUI)-based
GIS, the process of generating maps in GMT is a bit more complex, since it requires the understanding of the logic of its syntax which, due to the insufficient examples with open publications, may present certain difficulties in utilization. To give some examples of the GMT based coding, the following illustration of the technical approach is as follows. Selecting the study area and subset of the necessary region was done using a 'grdcut' module of GMT: 'grdcut GEBCO_2019.nc -R19/37/ 30.5/41.5 -Ght relief.nc'. Here the -R19/37/30.5/41.5 shows the geographic coordinates of the area in WestEast-South-North (WESN) format. Visualizing the raster image of the General Bathymetric Chart of the Oceans (GEBCO) was done by the 'grdimage' module which reads the $2 \mathrm{D}$ grid file in NetCDF and produces a coloured map using selected colour palette tables.

The core idea of raster image visualization by a 'grdimage' consists in plotting a series of rectangles centered on each grid node and assigning them with a colour based z-value, which corresponds to the topographic elevation value in meters. The colour palette table (cpt) in this case (see Figure 1) was defined by a module 'makecpt' through a command 'gmt makecpt -Cgeo.cpt -V -T- 


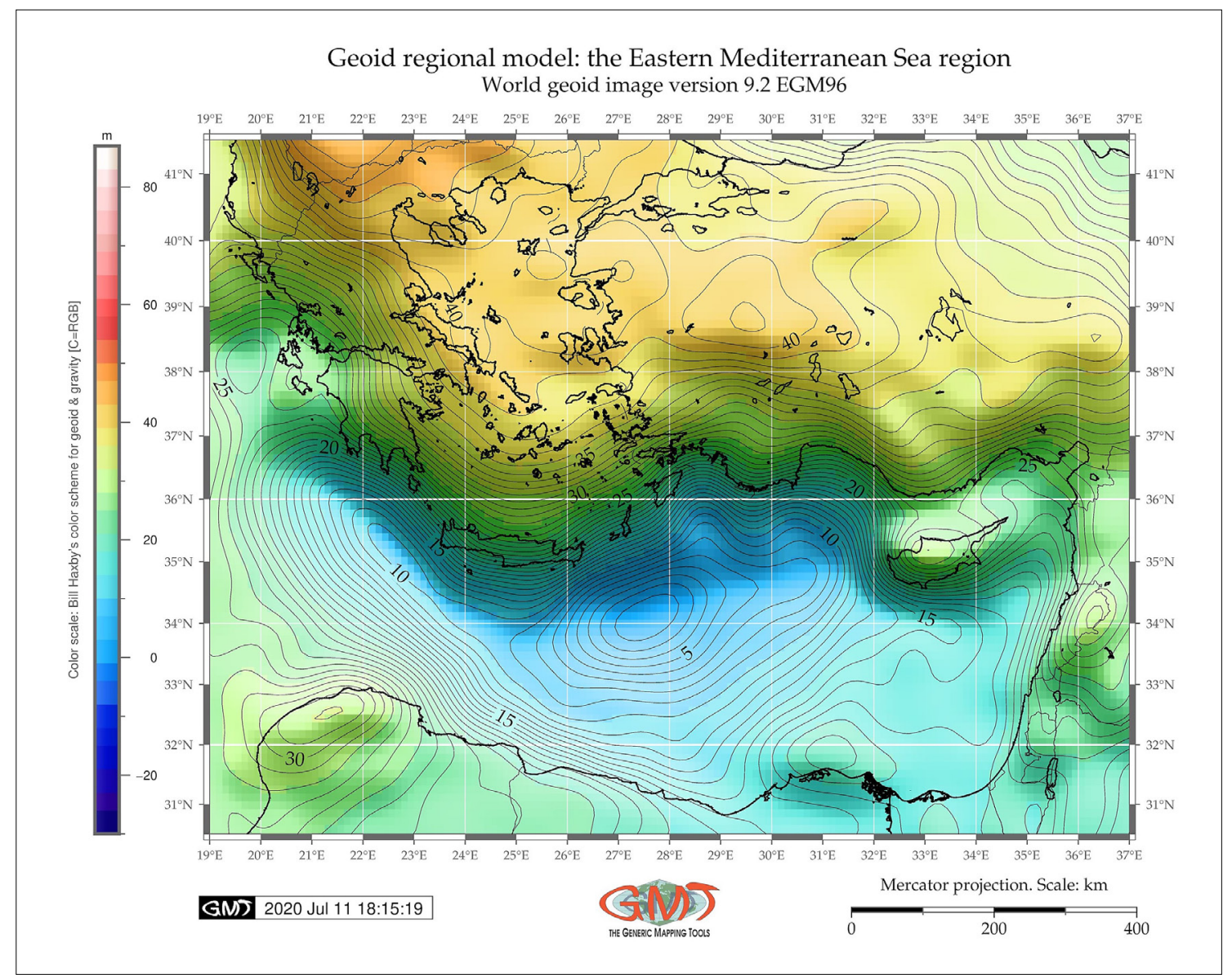

Figure 4: Geoid model of the Aegean Sea Basin. The geoid shows the equipotential level of the Earth surface through the irregular-shaped sphere, which best approximates the elevation of the mean sea level. In this sense, the geoid model is based on the terrestrial gravity observations, visualizing the density variations in the Earth's surface, topographic roughness and geological complexity (rock density) in the study area of the Hellenic Trench. The geoid of the eastern Mediterranean Sea region shows the equipotential surface representing a vertical datum of the Earth. The data area based on the EGM-96 geoid calculations (Lemoine et al. 1996). The lower, slightly negative values (-1 $\mathrm{m}$, blue coloured) are visible over the central basin of the Mediterranean Sea, while higher values are notable over the region of W Turkey (beige colours, over $40 \mathrm{~m}$ ).

$5119 / 3505>$ myocean.cpt'. The colour palette was placed vertically on the left side of the image. It shows a range of data from -5119 to $3505 \mathrm{~m}$. The image was then visualized by a code 'gmt grdimage ht relief.nc -Cmyocean.cpt -R19/37/30.5/41.5 -JM6i - $\overline{\mathrm{P}}-\mathrm{I}+\mathrm{a} 15+\mathrm{ne} 0.75$ $-\mathrm{Xc}-\mathrm{K}>$ \$ps'. Here the '-JM6i' flag stands for the Mercator projection, '-P' flag is a portrait orientation of the output, the -I option was used for the illumination of the image. The same principle was applied to all other cartographic elements plotted on the presented maps by GMT.

\subsection{Topographic visualization}

The first research phase has been designed as a geographical visualization of the topographic General Bathymetric Chart of the Oceans (GEBCO) and geological data. The actual processing of the raster GRD data consists of editing functions of the script where each line of the code generates a certain element on a map using a specific GMT module (e.g. 'grdimage', 'pscoast' and many more) and provides a layer-style mapping, which finally results in the design of a map. The data include high-resolution shoreline vector database (Wessel and Smith, 1996), tectonic plate boundaries and seismic events (focal mechanisms). The visualization aimed to show the consequences of the geological processes on geomorphological form of the deep-sea trench. The analysis of the data grids (their extent and spatial queries) was performed by Geospatial Data Abstraction Library (GDAL) library (GDAL/OGR contributors, 2020). The importance of the quality of the bathymetric and topographic grids has been discussed previously (Smith, 1993). To achieve a high standard of mapping, this research is based on the topographic grid of famous GEBCO map (GEBCO Compilation Group, 2020; Schenke, 2016) that provides the most authoritative, publicly available bathymetry data sets for the world's oceans. The GEBCO map is the most precise exiting global bathymetric map developed through the Nippon Foundation and is widely used in geophysical, geological and topographic mapping (Vrdoljak et al. 2021; 


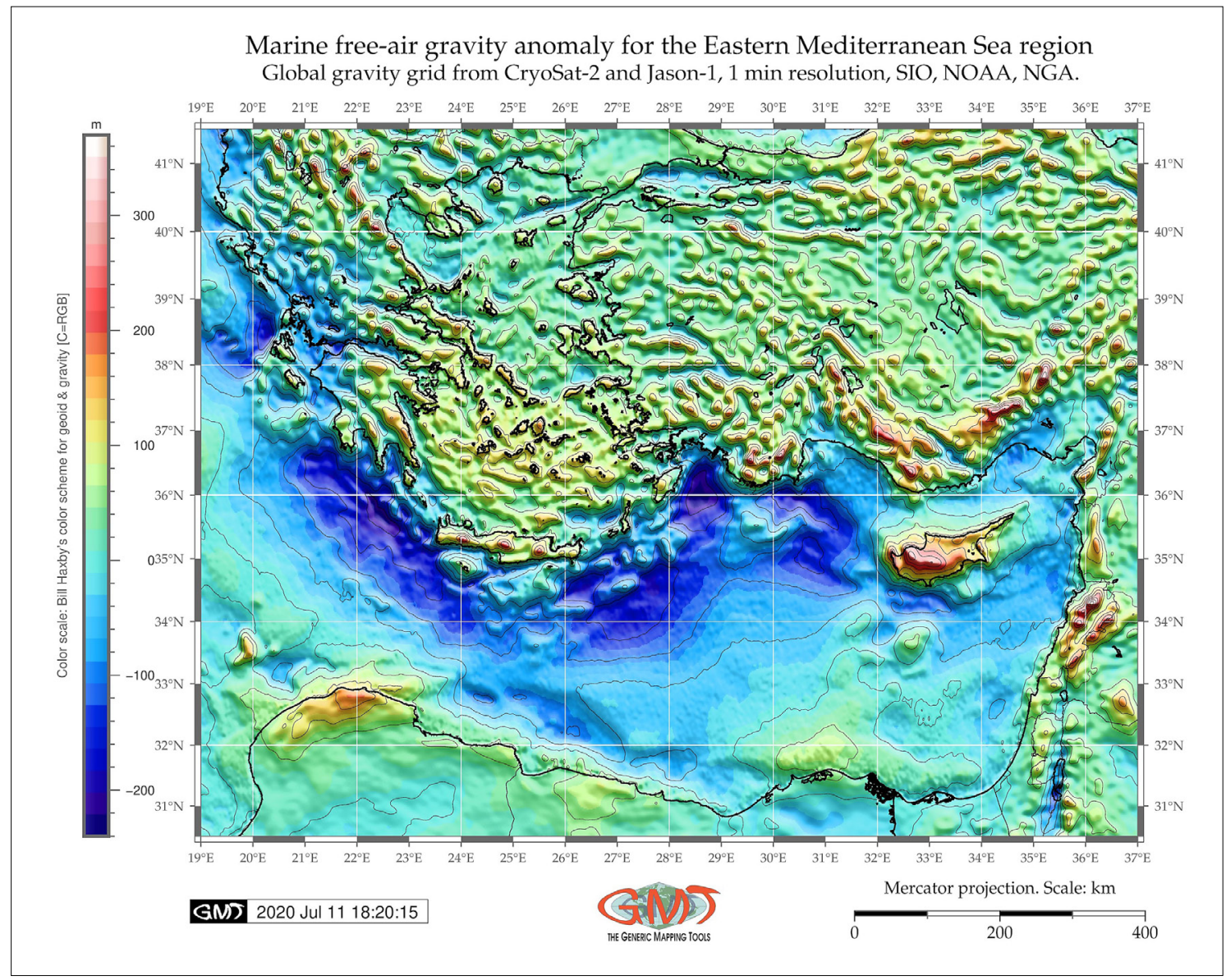

Figure 5: Marine free-air gravity anomaly for the Eastern Mediterranean Sea Basin. Free-air gravity anomaly visualization shows the distribution of the anomalous fields over the eastern Mediterranean Sea area and the Hellenic and Pliny trenches with respect to the subsurface Earth's structure and geophysical composition of the crust and mantle. The difference between the estimated gravity anomaly from a theoretical gravity value identifies anomalies caused by the geologic features below the measurement locations. The computation of

the free-air anomalies from the observed gravity measurements is based on the application of gravity corrections that control the resulting free-air gravity anomaly. Higher values (over $180 \mathrm{mGal}$, pink colours) are notable over the Island of Cyprus, and SE Turkey, while lower values (lower than -10o mGal, dark blue colours) are visible over the Hellenic and Pliny trenches, which shows a deficit in land masses in the depressions and points at the location of the deep-sea trenches.

Lemenkova, 2020e; Lemenkova, 2021b). It is a continuous, global terrain model for ocean and land with a spatial resolution of 15 arc seconds which uses as a base Version 2 of the Shuttle Radar Topography Mission (SRTM) data set (Tozer et al., 2019; Farr et al., 2007).

\subsection{Geophysical mapping}

In the second phase, the variations of the geophysical conditions, such as geoid (see Figure 4) and marine free-air gravity (see Figure 5), have been analyzed using the National Oceanic and Atmospheric Administration (NOAA) grid and Earth Gravitational Models of 1996 (EGM96) data (Lemoine et al., 1998). The GMT modules used for geophysical mapping implement a set of commands and defined settings ('flags') where a command is entered and defined. For example, the command 'gmt grdimage gravHT.grd -Ccolors.cpt -R19/37/30.5/
41.5 -JM6i -P -I+a15+ne0.75 -Xc -K > \$ps' was used to visualize the map in Figure 5 Marine free-air gravity map of the Aegean Sea Basin. Here the 'grdimage' is the main GMT module visualizing the raster grid, and the rest are auxiliary commands used to refine mapping and add elements on the map.

Analysis of the high-resolution data from the CryoSat-2, Jason-1 (Sandwell et al., 2014; Wessel and Watts, 1988) revealed regional differences in the rock properties that lead to diverse patterns of the gravity anomaly fields alongside existing geomorphic disparities of the submarine relief (Sandwell \& Smith, 1997). Published reports on geophysical and geological settings of the Aegean Sea in general and the Hellenic Trench system as its particular landform have been reviewed and considered for critical analysis of the above-mentioned issues (Papazachos and Comninakis, 1971; Angelier, 1977; Brun et al., 2016; Chamot-Rooke et al., 2005). 


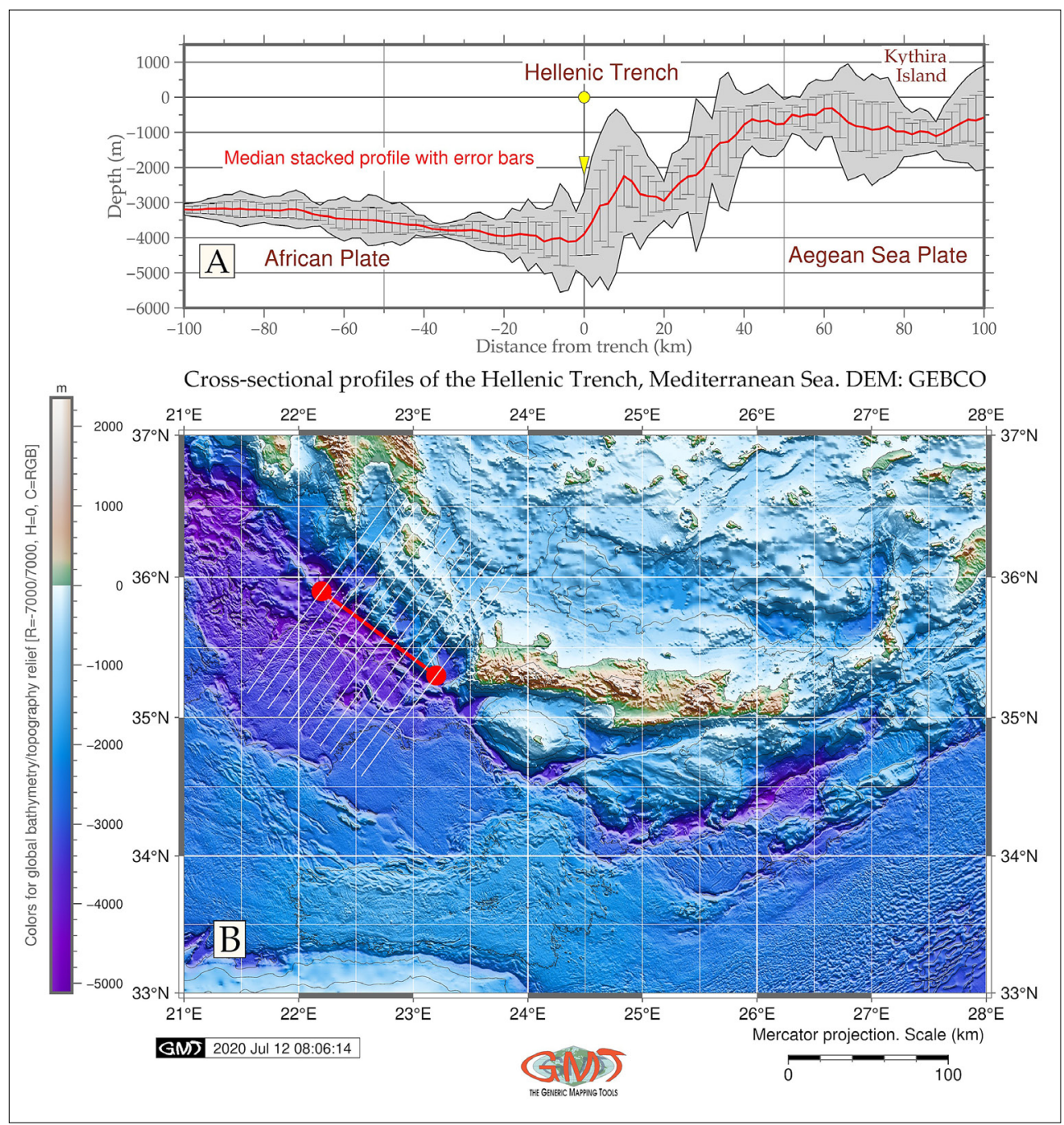

Figure 6: Cross-section profiles of the Hellenic Trench. Figure 6A shows the cross-sectional segments of the trench digitized automatically using GMT. Figure 6B shows the location and topography of the Hellenic Trench extending in the NW direction from SW Crete towards the Peloponnese Peninsula. The topographic pattern of Kythira Island and the adjacent region shows the increase in elevations on the right side of the flank of the segment. The greyed area (see Figure 6A) denotes the data deviations and thin vertical lines show error bars, while the thick red line shows the median value of the trench's talweg computed based on data from the 12 of profiles (thin yellow line in Figure 6B). The Aegean Sea Plate (minor tectonic plate) is located eastward of the trench, while the Africa Plate is on its western flank (see Figure 6B). The width of the profiles is $200 \mathrm{~km}$ with the talweg of the trench in the middle (see Figure $6 \mathbf{A}$ ).

\subsection{Geomorphological modelling}

In the third phase, the geomorphological modelling has been performed using scripting technologies (Lemenkova, 2020a, 2020b) for visualizing cross-section profiles of the Hellenic Trench (see Figure 6) and the Pliny Trench (see Figure 7), their comparative plotting and statistical analysis of histograms (see Figure 8). Automated digitizing of the cross-section profiles by GMT (Wessel et al. 2013) presents effective and advanced spatial data processing and information retrieval. The approach is based on the idea to speed up the vectorizing raster grids by machine learning: 1) first, the GMT is commanded to create a series of profiles running with set up parameters along a selected segment with defined coordinates; 2) the generated profiles create a table with three input columns (XY-coordinates of each cell and the measured elevation depth); 3) the GMT is commanded to use this table to plot a graph visualizing the profile as an output from a dataset.

Hence, the cross-section modelling allows for the plotting of a $2 \mathrm{D}$ transect for visualizing a geomorphological cross-section of the mountain relief in a given segment of the transect line of the relief to be mapped as a series as parallel-going lines crossing the target area in a perpendicular direction. The resulting geomorphological profiles can then be used for analysis of the topographic variations of the landforms. The representative 


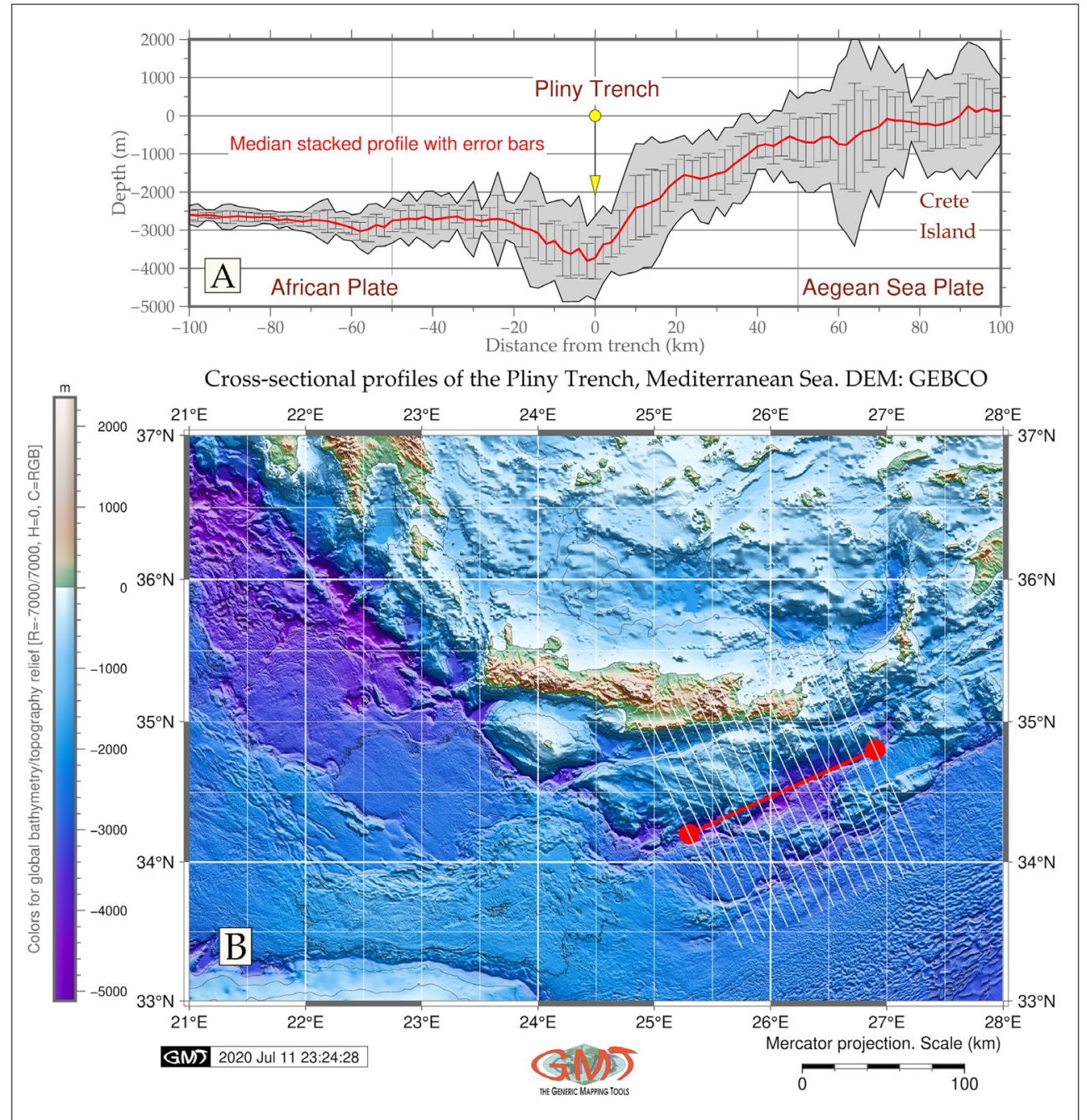

Figure 7: Cross-section profiles of the Pliny Trench. The thin yellow lines (see Figure ${ }_{7} \mathbf{B}$ ) represent the 17 cross-section profiles plotted as $200 \mathrm{~km}$ long parallel segments, sampled every $2 \mathrm{~km}$, spaced $10 \mathrm{~km}$ and stacked using the median (the thick red line in Figure $\mathbf{7 A}$ ). Raw bathymetric data originated from GEBCO (Schenke, 2016). The Pliny Trench extends from southern Crete in the NE direction (see Figure $7 \mathbf{B}$ ). The African Plate is located southwards of the trench, which is formed in the subduction zone. The map in Figure ${ }_{\mathbf{7}} \mathbf{B}$ shows the distribution of 17 transects of the cross-sections.

cross-sections for both trenches have following geometric characteristics: $200 \mathrm{~km}$ long, sampled every $2 \mathrm{~km}$, spaced $10 \mathrm{~km}$. The segment of the Hellenic Trench has coordinates: $22.2^{\circ} \mathrm{E} 35.9^{\circ} \mathrm{N}$ to $23.2^{\circ} \mathrm{E} 35.3^{\circ} \mathrm{N}$. The segment of the Pliny Trench has coordinates: $25.3^{\circ} \mathrm{E} 34.2^{\circ} \mathrm{N}$ to $26.9^{\circ} \mathrm{E} 34.8^{\circ} \mathrm{N}$.

\section{Results}

An analysis has been carried out based on a series of thematic maps (topographic, geologic, geophysical) and geomorphological models supported by the review of the existing extensive literature on the geology of the Eastern Mediterranean and the Hellenic Trench (Armijo et al., 1999; Baltatzis et al., 2009; Diogou et al., 2019; Fytikas et al., 1984; Ieite and Mascle, 1982). The topo- graphic map (see Figure 1) contains bathymetric characteristics of the Eastern Mediterranean Sea areas, depicting individual seafloor features and submarine geomorphic structures, based on the GEBCO 15-arc second resolution grid. The map visualized the Eastern Mediterranean Sea with the geographic names verified in the GEBCO Gazetteer of submarine features of International Hydrographic Organization, Intergovernmental Oceanographic Commission (IHO-IOC, 2012). Geological objects and sediment thickness are additionally shown in Figures 2 and 3, while the geophysical maps (see Figure 4 and 5) contain categories of marine free-air anomaly fields and geoid undulation.

The geologic data included several categories of objects related to geologic settings of the areas, that is, trenches and ridges, volcanoes, slabs, ophiolites, tecton- 


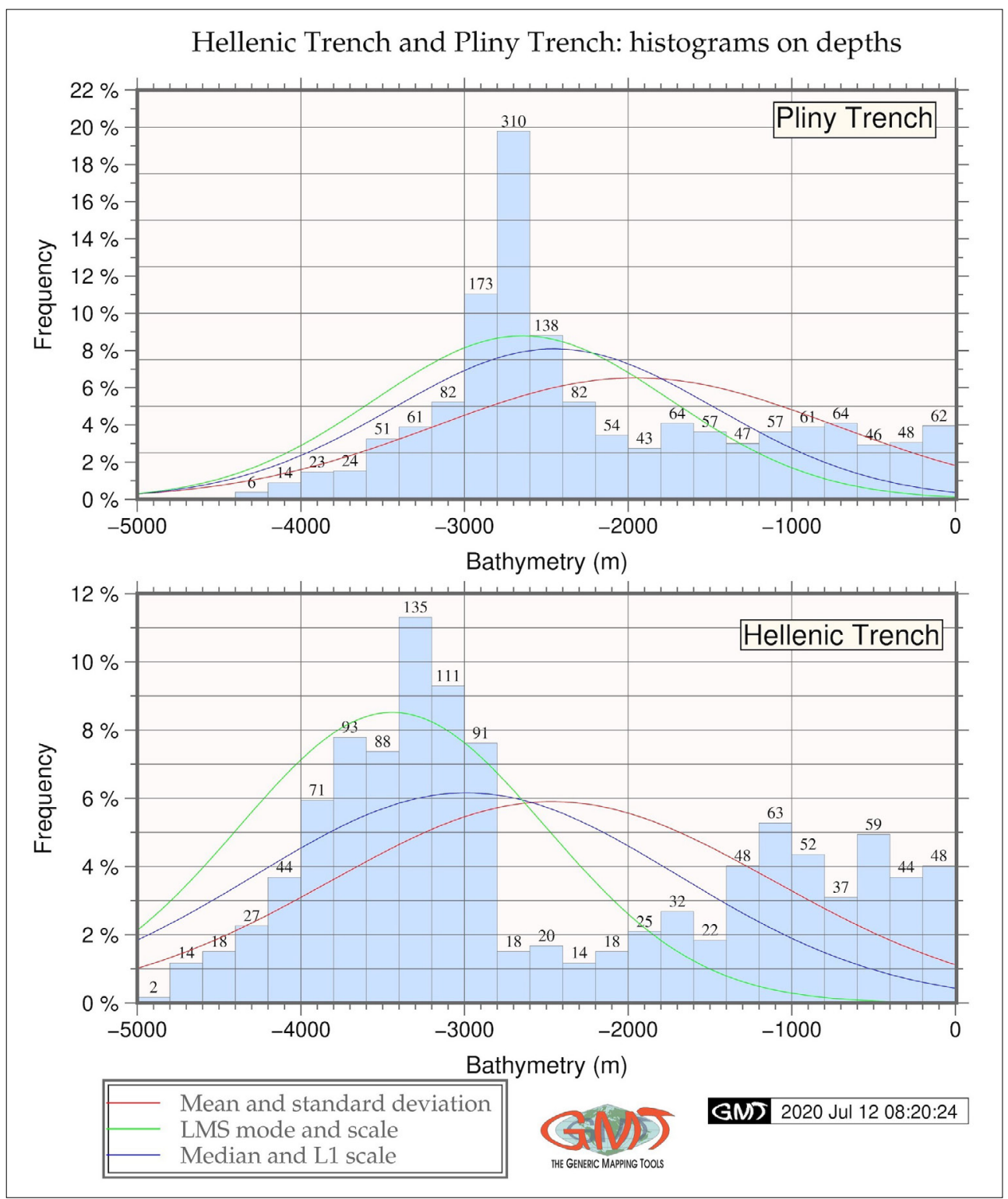

Figure 8: Statistical histograms of the of the Hellenic Trench cross-sections. Histograms of the bathymetric data distribution of the Hellenic and Pliny trenches showing the frequency of depths in 17 profiles for the Pliny Trench and 12 profiles for the Hellenic Trench. On the lower graph, the histogram is showing the peak of data for the Hellenic Trench in the interval between the -3.200 to $-3.400 \mathrm{~m}$ (135 samples), while the Pliny Trench shows the maximal data at the depths -2600 to $-2800 \mathrm{~m}$ (310 samples). Green (the least mean square), red (means and standard deviation) and blue (median) lines show additional statistical parameters of data distribution frequency for each of the trenches, respectively.

ic plate boundaries, and focal mechanisms (see Figure 2). The sediment thickness map visualizes the variations in sediment by categories divided by each $1000 \mathrm{~m}$, which corresponds to the previously obtained results (Erba et al., 1987; Feldhausen and Stanley, 1980). Thus, the highest sediment thickness can be seen (see Figure 3) near the Nile River discharge (over 9,000 m, beige colours on Figure 3) while the northern Aegean Sea seafloor and the region northward of Crete are notable for the lowest values of $<3,000 \mathrm{~m}$ (dark blue coloured areas). The Hellenic Trench system has varying values ranging between 7,000 and 8,000 m (light green areas) followed by 8,000 to $9,000 \mathrm{~m}$ (light orange-coloured areas). More detailed studies on the sediment structure of the Hellenic Trench can be found in Blanpied and Stanley (1981) who describe the depositional origin of fine-grained marine sediments caused by the well-exposed mudstone formations in the mountain chains in Greece and the Eastern Mediterranean Sea.

The map of the geoid regional model (see Figure 4) shows higher categories of the geoid undulation (35-45 $\mathrm{m})$ in the northern region of the Aegean Sea Basin con- 
tinuing over the terrestrial area of Bulgaria. The area to the southeast of Crete and the central part of the basin of the Eastern Mediterranean Sea demonstrate a notable regional decrease in geoid values $(50-10 \mathrm{~m}$, blue-coloured area). The region of the Hellenic Trench has dominating values of 11-12 m (light blue colour, Figure 4). A zone of the intense negative anomalies of Faye (-120 to -200 mGal) extends along the Hellenic Trench, which continues northward to the Adriatic Sea.

The lowest values of the free-air gravity are notable over the regions of the deep-sea trenches clearly depicting the physiographic isolines of the topographic map and showing correlation between the distribution of the depths and the anomaly fields (see Figure 5, dark blue colours). In contrast, the highest values $(>180 \mathrm{mGal})$ can be seen over the Cyprus Island area, as well as over the south-eastern territory of Turkey (light-orange to red colours in Figure 5). The majority of the terrestrial area of Turkey demonstrates a clear correlation between the gravity fields and topographic isolines of the mountain areas (light green to yellowish coloured areas as a hilly relief on Figure 5).

A comparison of the Hellenic Trench (see Figure 6) against the Pliny Trench (see Figure 7) shows that the Pliny Trench has a more symmetrical shape while the Hellenic Trench has an asymmetric one-sided shape with a steepness of $56.8^{\circ}$ on the northeastern side of the studied segment with coordinates $22.2^{\circ} \mathrm{E} 35.9^{\circ} \mathrm{N}$ to $23.2^{\circ} \mathrm{E}$ $35.3^{\circ} \mathrm{N}$ (see Figure 6B). The opposite southwestern flank is almost flat with a steepness of $7^{\circ}$ (see Figure 6A). The cross-track profiles are plotted as $200 \mathrm{~km}$ long, sampled every $2 \mathrm{~km}$, spaced $10 \mathrm{~km}$. The Pliny Trench has a segment stretching from $25.3^{\circ} \mathrm{E} 34.2^{\circ} \mathrm{N}$ to $26.9^{\circ} \mathrm{E} 34.8^{\circ} \mathrm{N}$ (see Figure 7B). It has a rather symmetric view in a cross-section with the following steepness: $42.14^{\circ}$ on its northwestern flank (crossing the eastern part of the Crete Island) and $26.66^{\circ}$ on its southeastern flank (see Figure 7A). Despite the certain difference in slope steepness of both the flanks of the Pliny Trench, it has a more symmetric geometric form comparing to the cross-section of the Hellenic Trench (the Ionian segment).

The comparative analysis of the statistical histograms (see Figure 8) shows the frequency of depths as data distributed along the segments of the Hellenic and Pliny trenches (see Figure 8). The analysis of the cross-section profile based on the summarized data shows the following results. The Pliny Trench (see Figure 8, upper part) has a clear peak of the most repetitive depths in an interval with a range $-2,600$ to $-2,800 \mathrm{~m}$ (310 samples) followed with a large gap by the intervals within depths -2800 to -3000 (173 samples) and an interval of -2400 to -2600 (138 samples). All other depths have values $<100$ samples with rather insignificant variations comparing to the depth at an interval of -2400 to $-3000 \mathrm{~m}$, which points at the most representative data range for the Pliny Trench between -5000 to $-6000 \mathrm{~m}$.

The Hellenic Trench demonstrates a different pattern of data variations. Thus, in contrast with the Pliny Trench showing a clear peak (see Figure 8), the Hellenic Trench has a bimodal data distribution. The data distribution has a bimodal character with two peaks corresponding to the two intervals: 1) a distinct peak at $-2800 \mathrm{~m}$ to $-4000 \mathrm{~m}$; and 2) a less pronounced peak at 0 to $-1400 \mathrm{~m}$. Other data values are located on the shelf and slopes. The most frequent bathymetric data for the Hellenic Trench correspond to the interval of $-3200 \mathrm{~m}$ to $-3400 \mathrm{~m}$ (135 samples). Comparing to the Pliny Trench, the Hellenic Trench is deeper with 105 values below the $-4,000 \mathrm{~m}$ while there are only 20 values at such depths for the Pliny Trench. Similarly, the range of data between the -4000 to $-3000 \mathrm{~m}$ has 241 values for the Pliny Trench while there are 498 data values for the Hellenic Trench.

This accordingly illustrates the difference in the depth distribution for the Hellenic Trench against the Pliny Trench. The comparison of shelf areas (depths of 0 to $-1,000 \mathrm{~m}$ ) shows relatively similar patterns: the Pliny Trench covers 281 observation points while the Hellenic Trench has 240 samples for the same data range. Thus, in the context of regional topographic analysis, the comparison of the histograms points at the difference in data distribution for the two trenches: a relatively wider, bimodal character of data distribution for a Hellenic Trench and a single-peaked data distribution for the Pliny Trench. The Hellenic Trench-Arc system has been investigated in only a few studies (Zelilidis et al., 2016; Royden and Papanikolaou, 2011; Huchon et al., 1982) comparing to the wide variety of other oceanic trenches of the Pacific Ocean, e.g., the famous Mariana Trench, the Peru-Chile Trench, the Kuril-Kamchatka Trench, the trenches of Oceania and the region of Australia (Lemenkova, 2019b, 2019c). This is mainly explained by the complex tectonic and geophysical settings of the Pacific Ocean comparing to the Mediterranean Sea (Chapple and Tullis, 1977; Lemenkova, 2021a; McClusky et al., 2000).

The existing papers on the Hellenic Trench are methodologically based on various methods. Among others, these include topographic mapping, visualization of slabs with a vertical tear or a lateral edge, GNSS-derived horizontal velocity field and seismicity, modelling geometry of the Hellenic subduction zone, visualizing Svelocity (Özbakır et al., 2020), studying structural trends in the Hellenic Trench system in context of the distribution of faults, folds and décollement types displacement (Kenyon et al., 1982). Other interesting publications include research focused on earthquakes and seismic reconstructions in the Hellenic Trench and the Aegean Sea area both in the past and in recent time (Papazachos and Papazachou, 2002; Evagelatou-Notara, 1993; Kiratzi et al., 2018; Di Vita, 1995).

However, the existing papers do not present geomorphological cross-sectioning of the trench using GMT, which fully illustrates the profile of the trenches as a comparative view, based on the new generation of cartographic scripting technologies. Previous studies in the 
Greek region (Crete Island and Hellenic Trench-Arc system) were restricted by the tectonic application and studies of the geological setting without a detailed focus on its submarine relief (Gautier et al., 1999; Jolivet et al., 2013; Konca et al., 2019; Papazachos, 1996). In this study, the geomorphology of the two trenches in the context of the regional geological settings was investigated using a dataset of high-resolution grids processed by the GMT approach. A comparison of the geomorphology of the Pliny and Hellenic trenches revealed significant variations in their cross-sections in the selected segments (plotted using 'grdtrack' modules of the GMT). This indicates the impact of the geological regional settings and rock stratification as well as the differences in speed of slab subduction in the two segments of the trenches. These factors sculpt the current geometric shape of the trenches.

\section{Conclusions}

The contextualization of this research in the era of big Earth data analysis and machine learning application presents a multi-disciplinary approach of geologic data processing by the GMT-based machine algorithms of geospatial data processing that allow to better understand the interaction between the seafloor geomorphology and tectonic-geologic setting sculpting the shape of a trench. The demonstrated GMT-based approach for mapping deep-sea trenches combines the scripting functionality that enables the performance of a high-quality mapping and cartographic visualization with the flexibility of programming. The existing scripts can be reused for the next steps of mapping and data analysis to save time and computer's memory and to decrease the repeatability of the monotonous process. The other advantage of the scripting based cartography is found in the significant automatization of the cartographic routine which enhances both the precision of the plotting and the quality of the output through avoiding humaninduced errors possible through the hand-made digitizing and mapping. Machine-made visualization of the geophysical grids, topographic and geological vector maps enable a comparative analysis of the multi-source data through their overlay with changed transparency settings and the location of layers within the cartographic script.

The actuality of the presented research on deep sea trenches is caused by the specific approach of this study. High-resolution geospatial datasets are one of the major drivers used for big Earth data analysis that consists of the processing of millions of cells and records in tables. The combination of high-resolution data (GEBCO, EGM96, GlobSed) and machine learning methods for processing of this data expands the functionality of the research projects of seafloor geomorphology. Since these unique submarine landforms are formed in the region of the tectonic plate subduction, active seismicity and submarine volcanism, their bathymetry is generally extremely deep and unavailable for direct observations. Therefore, studying deep-sea trenches was proven impractical until recent years. However, the rapid development of the machine learning methods and the onset of the big Earth data era enabled complex data analysis in marine geosciences. Some detailed studies of the submarine topography have been made over the mid-ocean ridges since the 1970s, but fewer studies were focused on the oceanic trenches.

The GMT scripting toolset is an effective cartographic visualization tool, alternative to traditional GIS. The power of automatization achieved through scripting facilitates the generation of maps as batch processing and enables the visualization and processing of large datasets in addition to mapping, statistical analysis, and data conversion. In contrast to GIS, GMT presents a completely console-based (no visual interface) scripting system for spatial analysis and cartographic mapping using a smart combination of modules and scripting approach using its native language. The advanced functionality of UNIX-compatible GMT enables the exportation of data from multiple formats and reprocesses them with GDAL processing tools. Furthermore, shell scripting by GMT automates the cartographic workflow, which becomes accurate and rapid, in contrast to the menu-based Graphical User Interface (GUI) GIS.

As a result, this increases the effectiveness of the cartographic methodology and presents fine print-quality cartographic output. Finally, another important feature of GMT consists in its open source availability, which presents perfect solutions to the distance-based (onlinebased) research, which is currently very useful for students and researchers alike. Unlike the commercial GIS, free GMT is available to 'work-at-home' projects, however, it has all the powerful cartographic functionalities: data import and formatting, data operation and organizing, data modelling, visualization and analysis. Besides, GMT is compatible with key libraries of the advanced statistical analysis such as Julia, Python (PyGMT for processing GMT's plots), R and Octave /MATLAB.

\section{Acknowledgment}

The author thanks two anonymous reviewers and the editor for their suggestions, helpful comments, corrections and remarks which improved both the text and some of the maps in the initial version of the document.

\section{References}

Angelier, J. (1977): Essai sur la néotectonique et les derniers stades tardi-tectoniques de l'arc Egéen et de l'Egée méridionale. Bulletin de la Société Géologique de France, XIX (3), 651-662. (in French)

Angelier, J. and Le Pichon, X. (1980): Neotectonique horizontale et verticale de l'Egée: subduction et expansion. Au- 
bouin, J. Debelmas and M. Latreille (Coordinators), Géologie des Chaînes Alpines Issues de la Téthys. Proceedings of the 26th International Geological Congress, Paris, January 1-7, 1980, Paris, Mém. BRGM 115, 249-260. (in French)

Angelier, J., Lybéris, N., Le Pichon, X., Barrier, E. and Huchon, P. (1982): The tectonic development of the hellenic arc and the Sea of Crete: A synthesis. Tectonophysics, 86, 159-196.

Armijo, R., Meyer, B., Hubert, A. and Barka, A. (1999): Westward propagation of the North Anatolian fault into the northern Aegean: Timing and kinematics. Geology, 27, 267-270.

Baltatzis, E., Kostopoulos, D., Godelitsas, A., Zachariadis, P. and Papanikolaou, D. (2009): Pliocene tourmaline rhyolite dykes from Ikaria Island in the Aegean back-arc region: geodynamic implications, Geodinamica Acta, 22, 4, 189199. https://doi.org/10.3166/ga.22.189-199

Bilić, Š. and Garašić, V. (2021): Petrological characteristics of clastic sedimentary rocks from the St. Barbara ore mine in Rude near Samobor. Rudarsko-geološko-Naftni Zbornik (The Mining-Geological-Petroleum Bulletin), 36, 1, 121$135 \mathrm{https}: / /$ doi.org/10.17794/rgn.2021.1.10

Blanpied, C. and Stanley, J.-D. (1981): Uniform Mud (Unifite) Deposition in the Hellenic Trench, Eastern Mediterranean. Smithsonian contributions to the marine sciences, 13, 1-49. https://doi.org/10.5479/si.01960768.13

Briševac, Z., Maričić, A., Brkić, V. and Bralić, V. (2021): An overview and future prospects of Croatian geotechnological heritage. Rudarsko-geološko-Naftni Zbornik (The Mining-Geological-Petroleum Bulletin), 36, 1, 77-89. https://doi.org/10.17794/rgn.2021.1.7

Brun, J.-P. and Sokoutis, D. (2010): 45 m.y. of Aegean crust and mantle flow driven by trench retreat. Geology 38(9), 815-818. https://doi.org/10.1130/G30950.1815-818

Brun J.-P., Faccenna C., Gueydan F., Sokoutis D., Philippon M., Kydonakis K. and Gorini C. (2016): Effects of Slab Rollback Acceleration on Aegean Extension. Bulletin of the Geological Society of Greece, 50, 5-14. https://doi. org/10.12681/bgsg. 11697

Chamot-Rooke, N., Rabaute, A. and Kreemer, C. (2005): Western Mediterranean Ridge mud belt correlates with active shear strain at the prism-backstop geological contact. Geology, 33, 11, 861-864.

Chapple, W.M. and Tullis, T.E. (1977): Evaluation of the forces that drive the plates. Journal of Geophysical Research, 82, 1967-1984. https://doi.org/10.1029/JB082i014p01967

Confal, J.M., Eken, T., Tilmann, F., Yolsal-Çevikbilen, S., Çubuk-Sabuncu, Y., Saygin, E. and Taymaz, T. (2016): Investigation of mantle kinematics beneath the Hellenicsubduction zone with teleseismic direct shear waves. Physics of the Earth and Planetary Interiors 261, Part B, 141-151. https://doi.org/10.1016/j.pepi.2016.10.012

Di Vita, A. (1995): Archaeologists and earthquakes: the case of 365 A.D. earthquake. Annali di geofizika, 38, 971-976.

Diogou, N., Klinck, H., Frantzis, A., Nystuen, J., Papathanassiou, E. and Katsanevakis, S. (2019): Year-round acoustic presence of sperm whales (Physeter macrocephalus) and baseline ambient ocean sound levels at the Hellenic Trench and the North Aegean Trough, Greece. Mediterranean Marine Science, 20, 1, 208-221. https://doi.org/10.12681/ mms. 18769

Dobrilović, I., Hrženjak, P. and Navratil, D. (2021): Development of a model for the estimation of shear strength of discontinuity in massive and karstified limestone. Rudarsko-geološko-Naftni Zbornik (The Mining-GeologicalPetroleum Bulletin), 36, 2, 43-57.https://doi.org/10.17794/ rgn.2021.2.5

Elsasser, W.M. (1971): Sea-floor spreading as thermal convection. Journal of Geophysical Research, 76, 1101-1112, https://doi.org/10.1029/JB076i005p01101

Erba, E., Parisi, E. and Cita, M.B. (1987): Stratigraphy and sedimentation in the western Strabo Trench, Eastern Mediterranean. Marine Geology 75, 1-4, 57-75. https://doi. org/10.1016/0025-3227(87)90096-X

Evagelatou-Notara, F. (1993): Earthquakes in Byzantium from 13th to 15 th century. A historical examination (in Greek with English summary). Parousia, 24, 1-184.

Farr, T.G., Rosen, P.A., Caro, E., Crippen, R., Duren, R., Hensley, S., Kobrick, M., Paller, M., Rodriguez, E., Roth, L., Seal, D., Shaffer, S., Shimada, J., Umland, J., Werner, M., Oskin, M., Burbank, D. and Alsdorf, D. (2007): The Shuttle Radar Topography Mission. Reviews of Geophysics, 45, RG2004. https://doi.org/10.1029/2005RG000183

Feldhausen, P.H. and Stanley, D.J. (1980): Hellenic Trench sedimentation: An approach using terrigenous distributions. Marine Geology 38, 4, M21-M30. https://doi. org/10.1016/0025-3227(80)90003-1

Fytikas, M., Innocenti, F., Manneti, P., Mazzuoli, R., Peccerillo, A. and Villari, L. (1984): Tertiary to Quaternary evolution of volcanism in the Aegean region. [in]: Dixon, J.G., Robertson, A.H.F., eds. The geological evolution of the Eastern Mediterranean: Geological Society of London Special Publication 17, 687-699.

Gauger, S., Kuhn, G., Gohl, K., Feigl, T., Lemenkova, P. and Hillenbrand, C. (2007): Swath-bathymetric mapping. Reports on Polar and Marine Research, 557, 38-45. https:// doi.org/10.6084/m9.figshare.7439231

Gautier, P., Brun, J.P., Moriceau, R., Sokoutis, D., Martinod, J. and Jolivet, L. (1999): Timing, kinematics and cause of Aegean extension: a scenario based on a comparison with simple analogue experiments. Tectonophysics, 315, 3172. https://doi.org/10.1016/S0040-1951(99)00281-4

Huchon, P., Lybéris, N., Angelier, J., Le Pichon, X. and Renard, V. (1982): Tectonics of the Hellenic trench: A synthesis of sea-beam and submersible observations. Tectonophysics 86 (1-3), 69-74. https://doi.org/10.1016/00401951(82)90062-2

Ieite, O. and Mascle, J. (1982): Geological structures on the South Cretan continental margin and Hellenic Trench (eastern Mediterranean). Marine Geology 49 (3-4), 199223. https://doi.org/10.1016/0025-3227(82)90040-8

Jagodnik, P., Bernat Gazibara, S., Jagodnik, V. and Mihalić Arbanas, S. (2020): Types and distribution of Quaternary deposits originating from carbonate rock slopes in the Vinodol Valley, Croatia - new insight using airborne LiDAR data. Rudarsko-geološko-Naftni Zbornik (The Mining- 
Geological-Petroleum Bulletin), 35, 4, 57-77. Retrieved from https://hrcak.srce.hr/ojs/index.php/rgn/article/view/ 11599

Jolivet, L., Faccenna, C., Huet, B., Labrousse, L., Le Pourhiet, L., Lacombe, O., Lecomte, E., Burov, E., Denèle, Y., Brun, J.P., Philippon, M., Paul, A., Salaün, G., Karabulut, H., Piromallo, C., Monié, P., Gueydan, F., Okay, A.I., Oberhänsli, R., Pourteau, A., Augier, R., Gadenne, L. and Driussi, O. (2013): Aegean tectonics: strain localisation, slab tearing and trench retreat. Tectonophysics 597, 1-33. https://doi.org/10.1016/j.tecto.2012.06.011

Kenyon, N.H., Belderson, R.H. and Stride, A.H. (1982): Detailed tectonic trends on the central part of the Hellenic Outer Ridge and in the Hellenic Trenh System. Geological Society London Special Publications, 335-343. https:// doi.org/10.1144/GSL.SP.1982.010.01.22

Kiratzi, A., Benetatos, C. and Vallianatos, F. (2018): Seismic Deformation Derived from Moment Tensor Summation: Application Along the Hellenic Trench. In: D'Amico S. (eds) Moment Tensor Solutions. Springer Natural Hazards. Springer, Cham, 233-251. https://doi.org/10.1007/978-3319-77359-9_10

Klaučo, M., Gregorová, B., Stankov, U., Marković, V. and Lemenkova, P. (2013a): Determination of ecological significance based on geostatistical assessment: a case study from the Slovak Natura 2000 protected area. Central European Journal of Geosciences, 5, 1, 28-42. https://doi. org/10.2478/s13533-012-0120-0

Klaučo, M., Gregorová, B., Stankov, U., Marković, V. and Lemenkova, P. (2014): Landscape metrics as indicator for ecological significance: assessment of Sitno Natura 2000 sites, Slovakia. In: Gritsuk, A.E. (ed.): Ecology and Environmental Protection. Proceedings of the International Conference, March 19-20, 2014. - Belarussian State University Press, Minsk, 85-90. https://doi.org/10.6084/m9. figshare.7434200

Klaučo, M., Gregorová, B., Stankov, U., Marković, V. and Lemenkova, P. (2017): Land planning as a support for sustainable development based on tourism: A case study of Slovak Rural Region. Environmental Engineering and Management Journal, 2, 16, 449-458. https://doi.org/ 10.30638/eemj.2017.045

Konca, A.O., Guvercin, S.E., Ozarpaci, S., Ozdemir, A., Funning, G.J., Dogan, U., Ergintav, S., Floyd, M., Karabulut, H. and Reilinger, R. (2019): Slip distribution of the 2017 Mw6.6 Bodrum-Kos earthquake: resolving the ambiguity of fault geometry. Geophysical Journal International, 219, 911-923. https://doi.org/10.1093/gji/ggz332

Krkač, M., Bernat Gazibara, S., Sečanj, M., Sinčić, M. and Mihalić Arbanas, S. (2021): Kinematic model of the slow moving Kostanjek landslide. Rudarsko-geološko-Naftni Zbornik (The Mining-Geological-Petroleum Bulletin), 36, 2, 59-68. https://doi.org/10.17794/rgn.2021.2.6

Kuhn, G., Hass, C., Kober, M., Petitat, M., Feigl, T., Hillenbrand, C. D., Kruger, S., Forwick, M., Gauger, S. and Lemenkova, P. (2006): The response of quaternary climatic cycles in the South-East Pacific: development of the opal belt and dynamics behavior of the West Antarctic ice sheet. In: Gohl, K. (ed). Expeditionsprogramm Nr. 75 ANT
XXIII/4, Alfred Wegener Institute Helmholtz Centre for Polar and Marine Research, 12-13. https://doi.org/10. 13140/RG.2.2.11468.87687

Lemenkov, V. and Lemenkova, P. (2021a): Using TeX Markup Language for 3D and 2D Geological Plotting. Foundations of Computing and Decision Sciences, 46, 3, 43-69. https:// doi.org/10.2478/fcds-2021-0004

Lemenkov, V. and Lemenkova, P. (2021b): Measuring Equivalent Cohesion Ceq of the Frozen Soils by Compression Strength Using Kriolab Equipment. Civil and Environmental Engineering Reports, 31, 2, 63-84. https://doi. org/10.2478/ceer-2021-0020

Lemenkova, P. (2021a): Geodynamic setting of Scotia Sea and its effects on geomorphology of South Sandwich Trench, Southern Ocean. Polish Polar Research, 42, 1, 1-23. https://doi.org/10.24425/ppr.2021.136510

Lemenkova, P. (2021b): The visualization of geophysical and geomorphologic data from the area of Weddell Sea by the Generic Mapping Tools. Studia Quaternaria 38, 1, 19-32. https://doi.org/10.24425/sq.2020.133759

Lemenkova, P. (2020a): Variations in the bathymetry and bottom morphology of the Izu-Bonin Trench modelled by GMT. Bulletin of Geography. Physical Geography Series, 18, 1, 41-60. https://doi.org/10.2478/bgeo-2020-0004

Lemenkova, P. (2020b): GMT Based Comparative Geomorphological Analysis of the Vityaz and Vanuatu Trenches, Fiji Basin. Geodetski List, 74, 1, 19-39. https://hrcak.srce. $\mathrm{hr} / 237683$

Lemenkova, P. (2020c): Java and Sumatra Segments of the Sunda Trench: Geomorphology and Geophysical Settings Analysed and Visualized by GMT. Glasnik Srpskog Geografskog Drustva, 100, 2, 1-23. https://doi.org/10.2298/ GSGD2002001L

Lemenkova, P. (2020d): Using GMT for 2D and 3D Modeling of the Ryukyu Trench Topography, Pacific Ocean. Miscellanea Geographica, 25, 3, 1-13. https://doi.org/10.2478/ mgrsd-2020-0038

Lemenkova, P. (2020e): GEBCO Gridded Bathymetric Datasets for Mapping Japan Trench Geomorphology by Means of GMT Scripting Toolset. Geodesy and Cartography, 46, 3, 98-112. https://doi.org/10.3846/gac.2020.11524

Lemenkova, P. (2019a): AWK and GNU Octave Programming Languages Integrated with Generic Mapping Tools for Geomorphological Analysis. GeoScience Engineering, 65, 4, 1-22. https://doi.org/10.35180/gse-2019-0020

Lemenkova, P. (2019b): Topographic surface modelling using raster grid datasets by GMT: example of the Kuril-Kamchatka Trench, Pacific Ocean. Reports on Geodesy and Geoinformatics, 108, 9-22. https://doi.org/10.2478/rgg2019-0008

Lemenkova, P. (2019c): GMT Based Comparative Analysis and Geomorphological Mapping of the Kermadec and Tonga Trenches, Southwest Pacific Ocean. Geographia Technica, 14, 2, 39-48. https://doi.org/10.21163/GT_2019. 142.04

Lemenkova, P. (2019d): Statistical Analysis of the Mariana Trench Geomorphology Using R Programming Language. Geodesy and Cartography, 45, 2, 57-84. https://doi.org/ 10.3846/gac.2019.3785 
Lemenkova, P., Promper, C. and Glade, T. (2012): Economic Assessment of Landslide Risk for the Waidhofen a.d. Ybbs Region, Alpine Foreland, Lower Austria. In: Eberhardt, E., Froese, C., Turner, A.K. and Leroueil, S. (eds.): Protecting Society through Improved Understanding. 11th International Symposium on Landslides and the 2nd North American Symposium on Landslides \& Engineered Slopes (NASL), June 2-8, 2012. Banff, AB, Canada, 279-285. https://doi.org/10.6084/m9.figshare.7434230

Lemoine, F.G., Kenyon, S.C., Factor, J.K., Trimmer, R.G., Pavlis, N.K., Chinn, D.S., Cox, C.M., Klosko, S.M., Luthcke, S.B., Torrence, M.H., Wang, Y.M., Williamson, R.G., Pavlis, E.C., Rapp, R.H. and Olson, T.R. (1998): NASA/ TP-1998-206861: The Development of the Joint NASA GSFC and NIMA Geopotential Model EGM96. NASA Goddard Space Flight Center, Greenbelt, Maryland, 20771 USA, 584 p.

Le Pichon, X. and Angelier, J. (1979): The Hellenic arc and trench system: a key to the neotectonic evolution of the eastern Mediterranean area. Tectonophysics, 60, 1-42. https://doi.org/10.1016/0040-1951(79)90131-8

Le Pichon, X., Huchon, P., Angelier, J., Lyberis, N., Boulin, J., Bureau, D., Cadet, J.P., Blanchet, R., Montadert, L., Dercourt, J., Glacon, G., Got, H., Karig, D., Mascle, J., Ricou, L.E. and Thiebault, F. (1981): Active tectonics in the Hellenic Trench. Oceanologica Acta, SP, 273-282. https://archimer.ifremer.fr/doc/00246/35697/

Le Pichon, X., Huchon, P., Angelier, J., Lybéris, N., Boulin, J., Bureau, D., Cadet, J.P., Dercourt, J., Glaçon, G., Got, H., Karig, D., Mascle, J., Ricou, L.E. and Thiebault, F. (1982): Subduction in the Hellenic Trench: probable role of a thick evaporitic layer based on Seabeam and submersible studies. Geological Society, London, Special Publications, 10, 319-333. https://doi.org/10.1144/GSL.SP.1982.010.01.21

Malovitsky, I.P., Chumakov, I.S. and Shimkus, K.M. (1982): The Earth's crust and the history of the development of the Mediterranean Sea. Nauka, Moscow, 207 p.

Maravelis, A., Panagopoulos, G., Piliotis, I., Pasadakis, N., Manoutsoglou, E. and Zelilidis, A. (2016): Pre-Messinian (Sub-Salt) Source-Rock Potential on Back-Stop Basins of the Hellenic Trench System (Messara Basin, Central Crete, Greece). Oil \& Gas Science and Technology - Rev. IFP Energies nouvelles, 71, 6, 1-19. https://doi.org/10.2516/ ogst $/ 2013130$

McClusky, S., Balassanian, S., Barka, A., Demir, C., Ergintav, S., Georgiev, I., Gurkan, O., Hamburger, M., Hurst, K., Kahle, H., Kastens, K., Kekelidze, G., King, R., Kotzev, V., Lenk, O., Mahmoud, S., Mishin, A., Nadariya, M., Ouzounis, A., Paradissis, D., Peter, Y., Prilepin, M., Reilinger, R., Sanli, I., Seeger, H., Tealeb, A., Toksöz, M.N. and Veis, G. (2000): Global positioning system constraints on plate kinematics and dynamics in the eastern Mediterranean and Caucasus. Journal of Geophysical Research, 105, 56955719. https://doi.org/10.1029/1999JB900351

McKenzie, D.P (1970): The plate tectonics of the Mediterranean region. Nature, 226, 239-243.

McPhee, P.J. and van Hinsbergen, D.J.J. (2019): Tectonic reconstruction of Cyprus reveals Late Miocene continental collision of Africa and Anatolia. Gondwana Research, 68, 158-173. https://doi.org/10.1016/j.gr.2018.10.015

Nugroho, S.H. and Putra, P.S. (2020): Determining textural and geochemical element characteristics of seafloor sediment using multivariate analysis along the Simeulue subbasin, Indonesia. Rudarsko-geološko-Naftni Zbornik (The Mining-Geological-Petroleum Bulletin), 35, 4, 79-92. Retrieved from https://hrcak.srce.hr/ojs/index.php/rgn/article/view/11420

Özbakır, A.D., Şengör, A.M.C., Wortel, M.J.R. and Govers, R. (2013): The Pliny-Strabo trench region: A large shear zone resulting from slab tearing. Earth and Planetary Science Letters, 375, 188-195. https://doi.org/10.1016/j.epsl.2013. 05.025

Özbakır, A.D., Govers, R. and Fichtner, A. (2020): The Kefalonia Transform Fault: A STEP fault in the making. Tectonophysics, 787, 1-17. https://doi.org/10.1016/j.tecto. 2020.228471

Papazachos, B.C. (1996): Large seismic faults in the Hellenic arc. Annali di Geofizica, XXXIX, 5, 891-903.

Papazachos, B.C. and Comninakis, P.E. (1971): Geophysical and tectonic features of the Aegean arc. Journal of Geophysical Research, 76, 8517-8533. https://doi.org/10.1029/ JB076i035p08517

Papazachos, B.C. and Papazachou, C.B. (2002): The earthquakes of Greece. Ziti Editions, Thessaloniki, 320 p.

Peters, J.M. and Huson, W.J. (1985): The Pliny and Strabo trenches (eastern Mediterranean): Integration of seismic reflection data and SeaBeam bathymetric maps. Marine Geology, 64, 1-2, 1-17. https://doi.org/10.1016/00253227(85)90157-4

Philippon, M., Brun, J.-P., Gueydan, F. and Sokoutis, D. (2014): The interaction between Aegean back-arc extension and Anatolia escape since Middle Miocene. Tectonophysics, 631, 176-188. https://doi.org/10.1016/j.tecto. 2014.04.039

Rabaute, A. and Chamot-Rooke, N. (2007): Quantitative mapping of active mud volcanism at the western Mediterranean Ridge-backstop contact. Marine Geophysical Research, 28, 271-295. https://doi.org/10.1007/s11001-007-9031-8

Ramberg, H. (1981): Gravity, Deformation, and the Earth's Crust, Theory, Experiments, and Geological Application. 2nd Revised edition. Academic Press Inc., London, 452 p.

Royden, L.H. and Papanikolaou, D.J. (2011): Slab segmentation and late Cenozoic disruption of the Hellenic arc. Geochemistry, Geophysics, Geosystems, 12, 3, 1-24. https:// doi.org/10.1029/2010GC003280

Sandwell, D.T. and Smith, W.H.F. (1997): Marine gravity anomaly from Geosat and ERS 1 satellite altimetry. Journal of Geophysical Research, 102, B5, 10039-10054. https://doi.org/10.1029/96JB03223

Sandwell, D.T., Müller, R.D., Smith, W.H.F., Garcia, E. and Francis, R. (2014): New global marine gravity model from CryoSat-2 and Jason-1 reveals buried tectonic structure. Science, 346, 6205, 65-67. https://doi.org/10.1126/science. 1258213

Schenke, H. (2016): General Bathymetric Chart of the Oceans (GEBCO). In: Harff J., Meschede M., Petersen S., Thiede J. 
(eds.): Encyclopedia of Marine Geosciences. Encyclopedia of Earth Sciences Series. - Springer, Dordrecht, 268-269, 950 p. https://doi.org/10.1007/978-94-007-6238-1_63

Schenke, H.W. and Lemenkova, P. (2008): Zur Frage der Meeresboden-Kartographie: Die Nutzung von AutoTrace Digitizer für die Vektorisierung der Bathymetrischen Daten in der Petschora-See. Hydrographische Nachrichten, 81, 16-21. https://doi.org/10.6084/m9.figshare. 7435538

Smith, W.H.F. (1993): On the accuracy of digital bathymetric data. Journal of Geophysical Research, 98, B6, 95919603. https://doi.org/10.1029/93JB00716

Straume, E.O., Gaina, C., Medvedev, S., Hochmuth, K., Gohl, K., Whittaker, J.M., Abdul Fattah, R., Doornenbal, J.C. and Hopper, J.R. (2019): GlobSed: Updated total sediment thickness in the world's oceans. Geochemistry, Geophysics, Geosystems, 20, 4, 1756-1772. https://doi.org/10.1029 /2018GC008115

Suetova, I.A., Ushakova, L.A. and Lemenkova, P. (2005): Geoinformation mapping of the Barents and Pechora Seas. Geography and Natural Resources, 4, 138-142. https://doi. org $/ 10.6084 / \mathrm{m} 9$. figshare. 7435535

Tirel, C., Gueydan, F., Tiberi, C. and Brun, J.P. (2004): Aegean crustal thickness inferred from gravity inversion. Geodynamical implications. Earth and Planetary Science Letters, 228, 267-280. https://doi.org/10.1016/j.epsl.2004.10.023

Tozer, B, Sandwell, D.T., Smith, W.H.F., Olson, C., Beale, J.R. and Wessel, P. (2019): Global bathymetry and topography at 15 arc sec: SRTM15+. Earth and Space Science, 6, 10, 1847-1864. https://doi.org/10.1029/2019EA000658

Truffert, C., Chamot-Rooke, N., Lallemant, S., De Voogd, B., Huchon, P. and Le Pichon, X. (1993): The crust of the Western Mediterranean Ridge from deep seismic data and gravity modelling. Geophysical Journal International, 114, 360372. https://doi.org/10.1111/j.1365-246X.1993.tb03924.x

Vassilakis, E., Royden, L. and Papanikolaou, D. (2011): Kinematic links between subduction along the Hellenic trench and extension in the Gulf of Corinth, Greece: A multidisciplinary analysis. Earth and Planetary Science Letters, 303, 1-2, 108-120. https://doi.org/10.1016/j.epsl.2010.12.054

Vrdoljak, L., Režić, M. and Petričević, I. (2021): Bathymetric and Geological Properties of the Adriatic Sea. Rudarskogeološko-Naftni Zbornik (The Mining-Geological-Petroleum Bulletin), 36, 2, 93-107. https://doi.org/10.17794/ rgn.2021.2.9

Wessel, P. and Watts, A.B. (1988): On the accuracy of marine gravity measurements. Journal of Geophysical Research, 93, 393-413. https://doi.org/10.1029/JB093iB01p00393
Wessel, P. and Smith, W.H.F. (1991): Free software helps map and display data. Eos Transactions of the American Geophysical Union 72, 41, 441-446. https://doi.org/10.1029 /90EO00319

Wessel, P. and Smith, W.H.F. (1995): New version of the Generic Mapping Tools released. Eos Transactions of the American Geophysical Union, 76, 33, 329-329. https:// doi.org/10.1029/95EO00198

Wessel, P. and Smith, W.H.F. (1996): A Global Self-consistent, Hierarchical, High-resolution Shoreline Database. Journal of Geophysical Research, 101, 8741-8743. https://doi. org/10.1029/96JB00104

Wessel, P., Smith, W.H.F., Scharroo, R., Luis, J.F. and Wobbe, F. (2013): Generic mapping tools: Improved version released. Eos Transactions AGU, 94, 45, 409-410. https:// doi.org/10.1002/2013EO450001

Zelilidis, A., Tserolas, P., Chamilaki, E., Pasadakis, N., Kostopoulou, S. and Maravelis, A.G. (2016): Hydrocarbon prospectivity in the Hellenic trench system: organic geochemistry and source rock potential of upper Miocene-lower Pliocene successions in the eastern Crete Island, Greece. International Journal of Earth Sciences (Geologische Rundschau), 105, 1859-1878. https://doi.org/10.1007/ s00531-015-1278-8

\section{Internet sources:}

URL: GDAL/OGR contributors (2020): GDAL/OGR Geospatial Data Abstraction software Library. Open Source Geospatial Foundation. https://gdal.org (accessed: 06 May 2021).

URL: GEBCO Compilation Group (2020): GEBCO 2020 Grid. https://doi.org/10.5285/a29c5465-b138-234d-e0536c86abc040b9 (accessed 7th May 2021).

URL: Divins, D. (2003): Total Sediment Thickness of the World's Oceans and Marginal Seas, Version 1. Boulder, CO: NOAA National Geophysical Data Center. https:// ngdc.noaa.gov/mgg/sedthick/sedthick.html (accessed 5th May 2021)

URL: IHO-IOC (2012): GEBCO Gazetteer of Undersea Feature Names. https:/www.gebco.net/data_and_products/ undersea_feature_names/(accessed 5th May 2021)

URL: Klaučo, M., Gregorová, B., Stankov, U., Marković, V. and Lemenkova, P. (2013b): Interpretation of Landscape Values, Typology and Quality Using Methods of Spatial Metrics for Ecological Planning. Poster at 54th International Conference Environmental and Climate Technologies, October 14, 2013. Riga, Latvia. https://doi.org/ 10.13140/RG.2.2.23026.96963 (accessed 10th May 2021). 


\section{SAŽETAK \\ Podmorska tektonska geomorfologija Plinijskoga i Helenskoga jarka kao odraz geološke evolucije južne Grčke}

Mapiranje geomorfologije morskoga dna složen je zadatak koji zahtijeva integraciju naprednih kartografskih tehnologija i prostornih podataka visoke rezolucije. Ovaj rad donosi usporednu geomorfološku analizu Helenskoga i Plinijskoga jarka smještenih u istočnome Sredozemlju, na jugu Grčke. Te su strukture nastale kao rezultat podvlačenja tektonske ploče, tj. kretanja afričke i arapske ploče prema sjeveru, usložnjenoga regionalnim geološkim postavkama poput aktivnih rasjeda i potresa, što je rezultiralo njihovim različitim geomorfološkim oblicima i batimetrijom. Prikazano je njihovo napredno kartiranje primjenom alata Generic Mapping Tools (GMT), koji koriste programske skripte. Karte se temelje na visokokvalitetnim topografskim, geološkim i geofizičkim podatcima, kao što su GEBCO, EGM96, geoid te gravitacijsko polje na razini mora. GMT se nadovezuje na module koji se koriste za obradu podataka. Područje je podijeljeno skriptom grdcut, a na temelju podataka iz zbirke apstraktnih geoprostornih podataka (GDAL) (skripta gdalinfo), te je na kraju vizualizirano (skripta grdimage). Dva dijela jarka oblikovana su u različitim geološkim i geofizičkim postavkama te su uspoređeni njihovi reprezentativni presjeci. Kao rezultat automatizirane digitalizacije, prostorne interpolacije i sekvencijalnoga agregiranja GMT kodova predstavljeni su segmenti presjeka. Helenski jarak (jonski segment) ima asimetričan jednostrani oblik, nagiba $56,8^{\circ}$ na sjeveroistočnoj i $7^{\circ}$ na jugozapadnoj strani. Plinijski je jarak simetričniji, nagiba $42,14^{\circ}$ na SZ i $26,66^{\circ}$ na JI boku. Plinijski jarak ima jasno izraženo tjeme od -2600 do -28oo m, a najreprezentativniji su podatci na -5000 do $-6000 \mathrm{~m}$. Helenski jarak ima bimodalnu distribuciju podataka s dvama tjemenima, a najčešće su dubine od -3200 do $-3400 \mathrm{~m}$. Taj je jarak dublji. Histogram prikazuje okupljanje podataka od -3200 do $-3400 \mathrm{~m}$, dok Plinijski (135 uzoraka) prikazuje maksimalne vrijednosti od -26oo do -280o m (310 uzoraka). Osim toga, 105 uzoraka Helenskoga jarka ima dubine veće od $-4000 \mathrm{~m}$, dok je u istome intervalu za Plinijski zabilježeno samo 20 uzoraka. Članak doprinosi geomorfološkim studijama regije istočnoga Sredozemnog mora općenito i regionalnomu mapiranju morskoga dna, posebno Helenskoga i Plinijskoga jarka.

\section{Ključne riječi:}

geofizika, generički alati za kartiranje, Helenski jarak, kartografija, geologija

\section{Author's contribution}

Polina Lemenkova (MSc, senior engineer, cartographer) performed all research steps: formulation of the problem and study goal, data collection, importing and converting to GMT via GDAL library, shell scripting, data processing and visualization, cartographic mapping, geomorphological modelling, statistical analysis, literature review on the Hellenic Trench and tectonics of the Mediterranean Sea, geologic analysis, preparing, writing and structuring of the manuscript. 